\title{
Osteoclast-like Cells Form in Long-term Human Bone Marrow but not in Peripheral Blood Cultures
}

\author{
N. Takahashi, T. Kukita, B. R. MacDonald, A. Bird, G. R. Mundy, L. M. McManus, " M. Miller, \\ A. Boyde, ${ }^{\ddagger}$ S. J. Jones, ${ }^{\ddagger}$ and G. D. Roodman \\ Veterans Administration Hospital and the Department of Medicine, ${ }^{*}$ Department of Pathology, University of Texas Health Science \\ Center, San Antonio, Texas 78284; and ${ }^{\ddagger}$ Department of Anatomy, University College, London, England
}

\begin{abstract}
Transplantation studies have suggested that peripheral blood mononuclear cells contain precursors for osteoclasts. Thus we tested the capacity of peripheral blood monocytes to form osteoclasts in long-term culture. We have reported previously that mononuclear cells from feline, baboon, and human marrow form osteoclast-like cells in long term cultures. Further, the formation of these cells is increased in response to bone resorption stimulatory agents such as PTH, interleukin 1, and transforming growth factor $\alpha$. We now report that these cells show characteristic cytoplasmic contraction with calcitonin and form resorption lacunae when cultured on sperm whale dentine. Thus, these bone marrow-derived multinucleated cells fulfill the functional criteria for osteoclasts. Although cultured peripheral blood monocytes can be induced to form multinucleated cells with 1,25-dihydroxyvitamin $D_{3}$, these cells did not show similar responses to the osteotropic factors as multinucleated cells formed in the bone marrow cultures multinucleated cells.

These results indicate that osteoclasts or cells closely related to osteoclasts form in long-term human bone marrow cultures. In contrast, few mononuclear cells in the peripheral blood appear capable of forming osteoclasts under the culture conditions used in these experiments.
\end{abstract}

\section{Introduction}

Osteoclasts are the primary mediators of bone resorption. These multinucleated giant cells form by fusion of mononuclear precursors derived from hemopoietic progenitor cells (1, 2 ). However, the precise nature of the osteoclast progenitor is unknown $(1,2)$.

We have developed (3-5) a long-term human bone marrow culture system in which multinucleated cells (MNC) ${ }^{1}$ form. These multinucleated cells display characteristics of osteoclasts including: (a) ultrastructural features ( 3$) ;(b)$ appropriate regulation of multinucleated cell formation by osteotropic hormones or factors (3-5); and (c) the presence of tartrate-re-

Address reprint requests to Dr. Roodman, Research Service (151), Audie Murphy Veterans Administration Medical Center, 7400 Merton Minter Blvd., San Antonio, TX 78284.

Received for publication 4 January 1988 and in revised form 30 August 1988.

1. Abbreviations used in this paper: MNC, multinucleated cells; TGF- $\alpha$, transforming growth factor.

The Journal of Clinical Investigation, Inc.

Volume 83, February 1989, 543-550 sistant acid phosphatase, a marker enzyme for osteoclasts. In this report we show that multinucleated cells that form in these cultures contract in response to calcitonin, a unique feature of mammalian osteoclasts, and form resorption lacunae when cultured on sperm whale dentine, a unique feature of both avian and mammalian osteoclasts.

Several studies (6-9) have suggested that osteoclast precursors are also present in peripheral blood as well as bone marrow. In parabiotic experiments Walker (6) and Gothlin and Ericsson (7) found that the osteoclasts that formed were derived from donor peripheral blood. Similarly, the transplantation studies of Walker (8) have shown that peripheral blood cells could cure osteopetrosis in lethally irradiated rodents. Further, Zambonin Zallone et al. (9) recently reported that chick peripheral blood monocytes can fuse with osteoclasts in vitro. Based on these data, we determined if human peripheral blood mononuclear cells could form osteoclasts in vitro. Although multinucleated cells formed in these cultures, these multinucleated cells differed from the osteoclast-like cells that formed in long term human marrow cultures. These data show that multinucleated cells that formed in long-term bone marrow but not peripheral blood cultures fulfill the functional criteria for osteoclasts.

\section{Methods}

Hormones and factors. 1,25-Dihydroxyvitamin $\mathrm{D}_{3}\left(1,25 \mathrm{D}_{3}\right)$ was generously provided by Dr. Uskokovic, Hoffmann-La Roche, Nutley, NJ. Bovine PTH (1-84) was obtained from the National Pituitary Agency, Baltimore, MD. Salmon calcitonin was purchased from Behring Diagnostics, La Jolla, CA. Recombinant human transforming growth factor alpha (TGF- $\alpha$ ) was kindly provided by Dr. R. L. Derynck, Genentech, Inc., South San Francisco, CA. Murine epidermal growth factor (EGF, receptor grade, 99\% pure by SDS PAGE) was obtained from Collaborative Research, Waltham, MA. Concentrations of TGF- $\alpha$ in terms of nanogram equivalents of EGF were measured by determining the amounts of TGF- $\alpha$ required to displace labeled EGF from its receptors (10). Partially purified IL-1 (15,000 D, pI 7.1), which was purified from human placenta, was kindly supplied by Dr. D. Wood, Ayerst Laboratory Research, New York.

Cultures of human bone marrow and peripheral blood mononuclear cells. Bone marrow aspirates and peripheral blood were obtained from normal donors or from patients who were without hematologic or endocrine disease and were undergoing autologous marrow transplantation. Bone marrow and blood for an experiment were obtained simultaneously from the same donor. Informed consent was obtained in all cases before marrow and blood collection. Bone marrow and peripheral blood mononuclear cells were isolated by centrifugation on Hypaque-Ficoll density gradients (Histopaque-1077; Sigma Chemical Co., St. Louis, MO) as previously described. Mononuclear cell fractions were washed three times with alpha minimal essential medium $(\alpha M E M)$ (Gibco Laboratories, Grand Island, NY). Bone marrow mononuclear cells were then cultured in $\alpha \mathrm{MEM}$ with $20 \%$ horse serum (Sterile System Inc., Logan, UT) at $10^{6}$ cells/ml in 24-well multiwell 
plates (Linbro, Flow Laboratories, McLean, VA) $(0.5 \mathrm{ml} /$ well). Cultures were fed weekly by removing half of the medium and replacing it with an equal volume of fresh medium (unless otherwise noted in the text). In preliminary experiments peripheral blood mononuclear cells were cultured in different media. Optimal MNC formation occurred when peripheral blood mononuclear cells were cultured in $\alpha$ MEM with $15 \%$ FCS (Sterile System Inc.) at $2 \times 10^{6}$ cells $/ \mathrm{ml}$ in 24 -well plates $(0.5 \mathrm{ml} /$ well). Cultures were fed twice weekly as described above. All cultures were maintained in a humidified atmosphere of $4 \% \mathrm{CO}_{2} /$ air at $37^{\circ} \mathrm{C}$. After designated periods of culture (usually $3 \mathrm{wk}$ ), cells were fixed with $5 \%$ glutaraldehyde (Sigma Chemical Co.), and stained with Wright's stain. Cells containing three or more nuclei were counted as multinucleated cells using an inverted phase microscope. In selected studies cells were evaluated for the presence of tartrate-resistant acid phosphatase or nonspecific esterase using commercial kits (Sigma Chemical Co.).

All results are expressed as the mean \pm SEM of three or four cultures per sample. Statistical significance was evaluated by a two-way analysis of variance for repeated measures or Student's $t$ test for paired samples when appropriate. Results were considered significant for $P<0.05$.

Time-lapse cinemicrography studies. Fetal baboon osteoclasts were isolated from fetal baboon long bones of $140 \mathrm{~d}$ gestational age baboons undergoing necropsy for other studies. Fetal baboon osteoclasts were used because no source of human osteoclasts was available for these studies, and baboon and human hematopoietic cells are very similar. After flushing the marrow cavity, long bones were split longitudinally and cut into small pieces. The bone pieces were pipetted vigorously and the large bone fragments removed. The cell suspension was pelleted by centrifugation and resuspended in $10 \mathrm{ml}$ of $\alpha \mathrm{MEM} / 15 \%$ FCS and plated in T-25 tissue culture flasks on the day of the study. The flasks were incubated for $2 \mathrm{~h}$ at $37^{\circ} \mathrm{C}$, nonadherent cells removed, and the media replaced. The flask was then tightly sealed and placed in $37^{\circ} \mathrm{C}$ incubator chamber of an inverted microscope fitted with a Bolex cinemicrography camera. Human bone marrow and peripheral blood mononuclear cells were cultured in T-25 flasks in the presence of $10^{-8}$ M $1,25 \mathrm{D}_{3}$ for $3 \mathrm{wk}$ as described above. The adherent cells were then washed three times with $\alpha \mathrm{MEM}$ and cultured in the absence of $1,25 \mathrm{D}_{3}$ in $\alpha$ MEM with $20 \%$ horse serum (bone marrow cultures) or $15 \%$ FCS (peripheral blood cultures) for $48 \mathrm{~h}$. Isolated osteoclasts, bone marrow-derived multinucleated cells or peripheral blood-derived multinucleated cells were photographed every $30 \mathrm{~s}$ using Kodak 16-mm plus-x film. The focus and microscopic field were not changed during the entire culture period. After a 16-h control period, calcitonin (100 $\mathrm{ng} / \mathrm{ml}$ ) was added to the cultures and the cells were photographed every $30 \mathrm{~s}$ for an additional $16 \mathrm{~h}$.

Resorption of sperm whale dentine. Sperm whale dentine slices were washed by ultrasonification for $10 \mathrm{~min}$ and sterilized by ultraviolet light irradiation overnight. Human bone marrow mononuclear cells $\left(10^{7}\right.$ cells) were cultured in the presence of $1,25 D_{3}$ for $2 \mathrm{wk}$ in T-25 flasks and the flasks were washed vigorously four times with PBS to remove nonadherent cells. $2 \mathrm{ml}$ of PBS containing $0.1 \%$ type 1 collagenase (Sigma), and $4 \mathrm{mM}$ EDTA were added, the flasks incubated at room temperature for $20 \mathrm{~min}$, and the cells collected by vigorous pipetting. The flasks were then washed three times with PBS and the washes and collagenase-treated cells were combined. The cells were then washed twice with $\alpha \mathrm{MEM} / 20 \%$ horse serum and then counted and resuspended in $0.2 \mathrm{ml} \alpha \mathrm{MEM} / 20 \%$ horse serum and $10^{-8} \mathrm{M}$ $1,25 \mathrm{D}_{3}$. The cell suspension was then plated on a dentine slice in a microtiter plate to which $50 \mu \mathrm{l}$ of $\alpha \mathrm{MEM} / 20 \%, 10^{-8} \mathrm{M} 1,25 \mathrm{D}_{3}$ had been previously added. The cells were incubated for $6 \mathrm{~d}$. $50 \mu \mathrm{l}$ of conditioned media from PTH stimulated SaOS osteosarcoma cells was then added, and the dentine slice incubated overnight. We have shown in preliminary experiments that $\mathrm{SaOS}$ conditioned media enhances formation of resorption lacunae. For control dentine slices, cells were not added but the dentine slices were otherwise treated in the same manner. The dentine slices were removed, kept moist with PBS, and the cells removed by gently rubbing the dentine between the thumb and first finger. The dentine was then fixed in $5 \%$ glutaraldehyde in 0.1
M sodium cacodylate buffer. The slices were then dehydrated, critical point dried, and sputter coated with gold. The specimens were then examined with a scanning electron microscope (model 500; Philips Electronic Instruments, Mahwah, NJ).

\section{Results}

Formation of multinucleated cells in long-term cultures of peripheral blood mononuclear cells. In our initial studies, the optimal conditions for long-term cultures of PBMCs were determined. $\alpha$ MEM with $15 \%$ FCS as a growth media was a better media for long-term peripheral blood cultures than $\alpha \mathrm{MEM}$ with $20 \%$ horse serum, which was used for long-term bone marrow cultures. Screening of different lots of FCS demonstrated considerable variation in their ability to support these peripheral blood cultures. Therefore a single lot of FCS was selected and used for all subsequent experiments. Heat inactivation of serum was not done because it promoted clumping of cells that detached from the culture vessel. The number of multinucleated cells that formed in 25 separate peripheral blood cultures initially containing $10^{6}$ cells per culture and lacking added osteotropic hormones was $25 \pm 10$ (mean \pm SEM, range $0-146$ ). The average number of nuclei per MNC was $5.3 \pm 0.3$ (mean \pm SEM) with a range of 3 to 20 . Peripheral blood-derived multinucleated cells contained nonspecific esterase and tartrate-resistant acid phosphatase.

Effects of $1,25 D_{3}$ on $M N C$ formation. As previously reported (3), addition of $1,25 \mathrm{D}_{3}$ at $10^{-8} \mathrm{M}$ to bone marrow cultures markedly stimulated multinucleated cell formation and maximal formation occurred after $3 \mathrm{wk}$ of culture (Fig. 1 $A$ ). Few multinucleated cells formed in bone marrow cultures lacking added osteotropic hormones. Similarly, $1,25 \mathrm{D}_{3}$ stimulated multinucleated cell formation in peripheral blood cultures (Fig. $1 \mathrm{~B}$ ). In bone marrow cultures, $10^{-10} \mathrm{M} 1,25 \mathrm{D}_{3}$ significantly increased the number of multinucleated cell and $10^{-8} \mathrm{M} 1,25 \mathrm{D}_{3}$ maximally stimulated multinucleated cell formation after 3 wk of culture (Fig. $2 \mathrm{~A}$ ). A similar dose-response curve for $1,25 \mathrm{D}_{3}$ stimulated multinucleated cell formation was seen in peripheral blood cultures in six of seven experiments

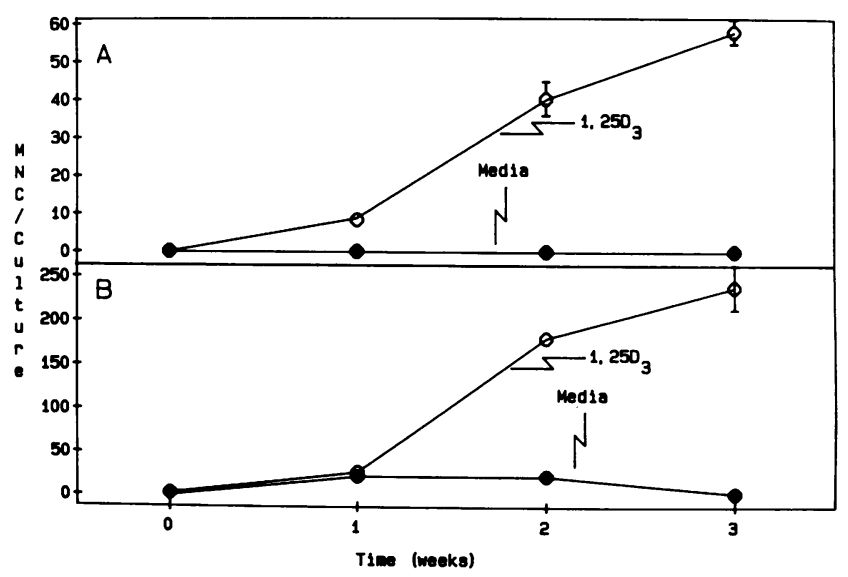

Figure 1. Time course of MNC formation in bone marrow and peripheral blood cultures. Human bone marrow $(A)$ or peripheral blood $(B)$ mononuclear cells were cultured with $(0)$ or without $(\bullet)$ $10^{-8} \mathrm{M}$ of $1,25 \mathrm{D}_{3}$ as described in Methods. After indicated culture periods, cells were fixed, stained, and MNCs were counted. The points show the mean \pm SEM of four cultures. 


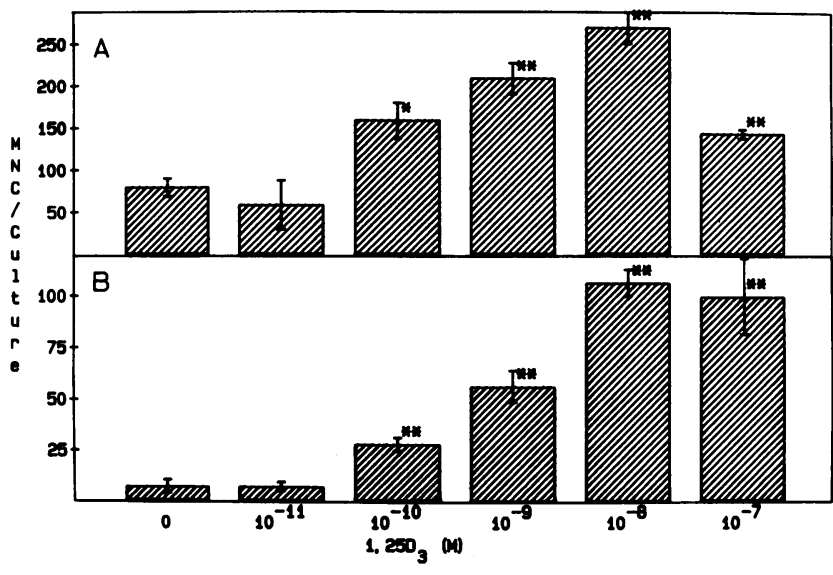

Figure 2. Effects of varying concentrations of $1,25 \mathrm{D}_{3}$ on $\mathrm{MNC}$ formation in bone marrow and peripheral blood cultures. Bone marrow $(A)$ or peripheral blood $(B)$ mononuclear cells were cultured with varying concentrations of $1,25 \mathrm{D}_{3}$. After $3 \mathrm{wk}$ of culture, MNCs were scored. The results represent the mean \pm SEM of three or four cultures. ${ }^{*} P<0.05$ compared to cultures lacking added $1,25 \mathrm{D}_{3}$. ${ }^{* *} P<0.01$ compared to cultures lacking added $1,25 \mathrm{D}_{3}$.

(Fig. 2 B). Multinucleated cells formed in bone marrow cultures stimulated with $1,25 \mathrm{D}_{3}$ contained $7.1 \pm 0.5$ (mean $\pm \mathrm{SEM}$, range 3-18) nuclei per cell while multinucleated cells formed in peripheral blood cultures contained $15.1 \pm 0.7$ (mean \pm SEM, range 8-27) nuclei per cell.

Effects of PTH. Addition of PTH to bone marrow cultures significantly stimulated multinucleated cell formation (Fig. 3 A). PTH at 25 to $100 \mathrm{ng} / \mathrm{ml}$ significantly increased the number of multinucleated cells in seven of eight bone marrow cultures. In contrast, PTH had no effect on multinucleated cell formation in peripheral blood cultures (Fig. $3 \mathrm{~B}$ ).

Effects of calcitonin. We then compared the effects of calcitonin on formation of multinucleated cells in bone marrow and peripheral blood cultures. In bone marrow cultures, calcitonin alone had no effect on basal multinucleated cell forma-

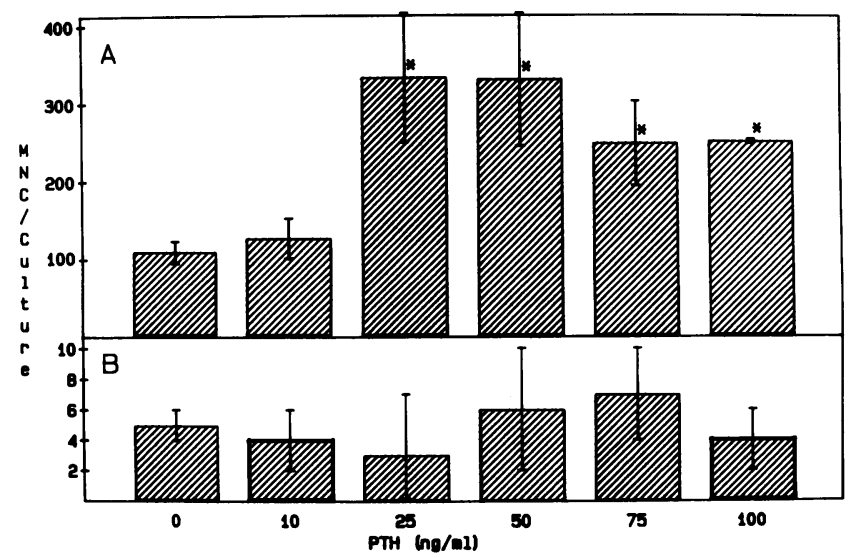

Figure 3. Effects of PTH on MNC formation in bone marrow and peripheral blood cultures. Bone marrow $(A)$ or peripheral blood $(B)$ mononuclear cells were cultured with varying concentrations of bovine PTH (1-84). After 3 wk of culture MNCs were scored. The results represent the mean \pm SEM for three or four cultures. ${ }^{*} P<0.05$ compared to cultures lacking added PTH. tion but strongly inhibited multinucleated cell formation stimulated by $1,25 \mathrm{D}_{3}$ (Table I). In contrast, calcitonin failed to inhibit multinucleated cell formation in peripheral blood cultures treated with $1,25 \mathrm{D}_{3}$ (Table I). Calcitonin also inhibited formation of multinucleated cells stimulated by PTH in bone marrow cultures but had no effect on peripheral blood cultures (Table II).

Effects of TGF- $\alpha$ and EGF. TGF- $\alpha$ (10-14) and EGF (15, 16) have been shown to stimulate osteoclastic bone resorption in vitro. We have previously shown that TGF- $\alpha$ and EGF stimulate multinucleated cell formation in bone marrow cultures by stimulating the proliferation of precursors for these cells (4). Therefore, we compared the effects of TGF- $\alpha$ and EGF on multinucleated cell formation in bone marrow and peripheral blood mononuclear cell cultures. Addition of recombinant human TGF- $\alpha(0.1 \mathrm{ng} / \mathrm{ml})$ to bone marrow cultures for the first week or for the whole $3 \mathrm{wk}$ did not increase the number of multinucleated cells after 3 wk of culture (Fig. 4 $B)$. However, treatment of bone marrow cultures with TGF- $\alpha$ for the first week and followed by the treatment with $1,25 \mathrm{D}_{3}$ $\left(10^{-8} \mathrm{M}\right)$ for the last $2 \mathrm{wk}$ significantly increased the number of multinucleated cells compared with corresponding control cultures treated with $1,25 \mathrm{D}_{3}$ alone for the last 2 wk (Fig. $4 \mathrm{~B}$ ). TGF- $\alpha$, however, failed to increase the number of multinucleated cells in peripheral blood cultures subsequently treated with $1,25 \mathrm{D}_{3}$ (Fig. $4 \mathrm{~A}$ ).

Similarly, treatment of bone marrow cultures with murine EGF $(10 \mathrm{ng} / \mathrm{ml})$ for the first week and followed by $1,25 \mathrm{D}_{3}$ for the last 2 wk significantly stimulated multinucleated cell formation (Fig. $5 \mathrm{~B}$ ). In contrast, multinucleated cell formation in peripheral blood cultures was not affected by the treatment with EGF (Fig. $5 \mathrm{~A}$ ).

Effects of $I L-1$. IL-1, a monocyte product, has been reported to be a potent stimulator for osteoclastic bone resorption (17-20). Treatment of bone marrow cultures with purified IL-1 $(100 \mathrm{U} / \mathrm{ml})$ for 3 wk markedly stimulated multinucleated cell formation (Table III). However, no significant increase in the number of multinucleated cells was observed in peripheral blood cultures treated with IL-1 (Table III).

Table I. Effect of Calcitonin on MNC Formation in Bone Marrow and Peripheral Blood Mononuclear Cell Cultures Treated with $1,25 D_{3}$

\begin{tabular}{|c|c|c|c|c|}
\hline \multirow[b]{2}{*}{ Treatment } & \multicolumn{2}{|c|}{ Bone marrow culture } & \multicolumn{2}{|c|}{ Peripheral blood culture } \\
\hline & Exp. 1 & Exp. 2 & Exp. 1 & Exp. 2 \\
\hline & \multicolumn{2}{|c|}{ MNC/Culture } & \multicolumn{2}{|c|}{ MNC/Culture } \\
\hline Media & $4 \pm 1$ & $186 \pm 4$ & $3 \pm 1$ & $64 \pm 28$ \\
\hline $1,25 \mathrm{D}_{3}$ & $190 \pm 12^{*}$ & $543 \pm 53^{*}$ & $568 \pm 149^{*}$ & $176 \pm 27^{*}$ \\
\hline Calcitonin & $11 \pm 4$ & $189 \pm 43$ & $18 \pm 8$ & ND \\
\hline $1,25 D_{3}+$ Calcitonin & $70 \pm 14^{\ddagger}$ & $334 \pm 25^{\S}$ & $439 \pm 68$ & $190 \pm 18$ \\
\hline
\end{tabular}

Human bone marrow or peripheral blood mononuclear cells were cultured with or without $1,25 \mathrm{D}_{3}\left(10^{-8} \mathrm{M}\right)$. Calcitonin $(100 \mathrm{ng} / \mathrm{ml})$ was added to some cultures at the start of culture. After $3 \mathrm{wk}$ of culture, cells were fixed, stained and MNCs were scored. The results are expressed as the mean \pm SEM for three or four cultures.

* $P<0.01$ compared to cultures lacking added $1,25 \mathrm{D}_{3}$.

${ }^{\ddagger} P<0.01$ compared to cultures treated with $1,25 \mathrm{D}_{3}$.

$\S P<0.05$ compared to cultures treated with $1,25 \mathrm{D}_{3}$. 
Table II. Effects of Calcitonin on MNC Formation in Bone Marrow and Peripheral Blood Mononuclear Cell Cultures Treated with PTH

\begin{tabular}{lcccccc}
\hline & \multicolumn{3}{c}{ Bone marrow culture } & & \multicolumn{2}{c}{$\begin{array}{c}\text { Peripheral blood } \\
\text { culture }\end{array}$} \\
\cline { 2 - 2 } \cline { 5 - 6 } Treatment & \multicolumn{2}{c}{ Exp. 1 } & Exp. 2 & & Exp. 1 & Exp. 2 \\
\cline { 2 - 3 } & \multicolumn{2}{c}{$M N C /$ Culture } & & \multicolumn{2}{c}{$M N C /$ Culture } \\
Media & $10 \pm 3$ & $2 \pm 1$ & & $9 \pm 7$ & $12 \pm 2$ \\
PTH & $33 \pm 7^{*}$ & $29 \pm 4^{*}$ & & $11 \pm 7$ & $13 \pm 2$ \\
PTH + CT & $13 \pm 2^{\ddagger}$ & $7 \pm 2^{\ddagger}$ & & $12 \pm 5$ & $19 \pm 5$ \\
& & & & & \\
\hline
\end{tabular}

Human bone marrow or peripheral blood mononuclear cells were cultured in the presence or absence of PTH $(50 \mathrm{ng} / \mathrm{ml})$ and/or calcitonin $(100 \mathrm{ng} / \mathrm{ml})$. After $3 \mathrm{wk}$ of culture, cells were fixed, stained, and MNCs were scored. The results are expressed as the mean \pm SEM for three or four cultures.

${ }^{*} P<0.01$ compared to cultures lacking added PTH.

${ }^{\ddagger} P<0.01$ compared to cultures treated with PTH.

Time-lapse cinemicrography studies. Chambers and Magnus (21) first demonstrated that calcitonin added to freshly isolated mammalian osteoclasts induces cytoplasmic contraction and immotility in these cells but had no effect on macrophage polykaryons. Therefore, the effects of calcitonin on the behavior of freshly isolated baboon osteoclasts, bone marrow-derived multinucleated cells and peripheral blood-derived multinucleated cells, were compared by time-lapse cinemicrography (Fig. 6). Addition of calcitonin to isolated osteoclasts (Fig. $6 \mathrm{~B}$ ) or to bone marrow-derived multinucleated cells (Fig. $6 \mathrm{D}$ ) resulted in marked cytoplasmic contraction and decreased motility of the cells. These effects were seen within 30 min after addition of calcitonin and persisted for 10-14 h.

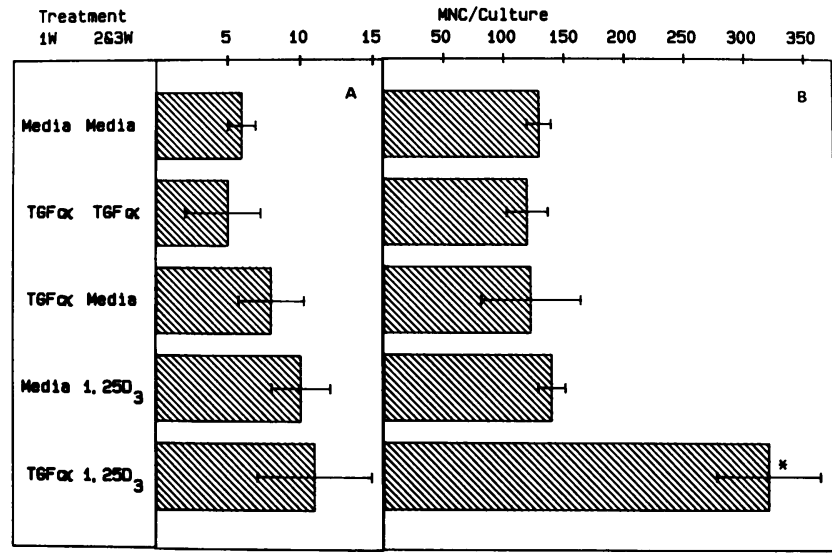

Figure 4. Effects of TGF- $\alpha$ on MNC formation in bone marrow and peripheral blood cultures. Peripheral blood $(A)$ or bone marrow $(B)$ mononuclear cells were cultured in the presence or absence of human recombinant TGF- $\alpha(0.1 \mathrm{ng} / \mathrm{ml})$ for $1 \mathrm{wk}$. The medium was then removed and the fresh medium was added to the culture. Nonadherent cells removed with the spent medium were recovered by centrifugation and replaced with fresh medium. $1,25 \mathrm{D}_{3}$ was then added to selected cultures. After $3 \mathrm{wk}$ of culture, MNCs were scored. The results represent the mean \pm SEM for three or four cultures. ${ }^{*} P$ $<0.01$ compared to cultures treated with $1,25 \mathrm{D}_{3}$ for the last $2 \mathrm{wk}$.

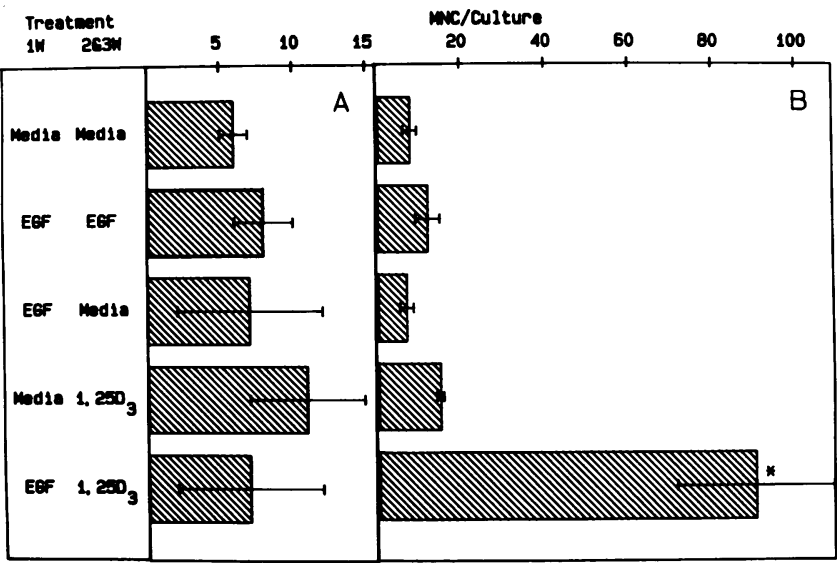

Figure 5. Effects of EGF on MNC formation in bone marrow and peripheral blood cultures. Peripheral blood $(A)$ or bone marrow $(B)$ mononuclear cells were cultured in the presence or absence of murine EGF $(10 \mathrm{ng} / \mathrm{ml})$ or $1,25 \mathrm{D}_{3}\left(10^{-8} \mathrm{M}\right)$ as described in the legend to Fig. 4. After 3 wk of culture, MNCs were scored. The results represent the mean \pm SEM for three or four cultures. ${ }^{*} P<0.01 \mathrm{com}-$ pared to cultures treated with $1,25 \mathrm{D}_{3}$ for the last $2 \mathrm{wk}$.

It is interesting that $45-50 \%$ of multinucleated cells formed in bone marrow cultures did not respond in this manner to calcitonin. In contrast, none of the multinucleated cells that formed in peripheral blood cultures were affected by the treatment with calcitonin (Fig. $6 F$ ).

Resorption of sperm whale dentine. Osteoclasts form resorption lacunae when cultured on sperm whale dentine (22, $23)$ or bone $(24,25)$ in vitro. In contrast, macrophage polykaryons do not form these lacunae $(26,27)$. Therefore, we determined if marrow or peripheral blood-derived multinucleated cells formed resorption lacunae when cultured on dentine. Dentine was chosen as the test matrix because it contains no osteocyte lacunae to confuse the interpretation of the results $(22,23)$. Bone marrow-derived multinucleated cells formed resorption lacunae on sperm whale dentine (Fig. 7) with the number of definite resorption lacunae being $1-10 \%$ of the number of total multinucleated cells plated on five separate experiments. Peripheral blood derived multinucleated cells did not form resorption lacunae on sperm whale dentine regardless of the number of cells plated.

Table III. Effects of IL-1 on MNC Formation in Bone Marrow and Peripheral Mononuclear Cell Blood Cultures

\begin{tabular}{|c|c|c|c|c|}
\hline \multirow[b]{2}{*}{ Treatment } & \multicolumn{2}{|c|}{ Bone marrow culture } & \multicolumn{2}{|c|}{$\begin{array}{l}\text { Peripheral blood } \\
\text { culture }\end{array}$} \\
\hline & Exp. 1 & Exp. 2 & Exp. 1 & Exp. 2 \\
\hline & \multicolumn{2}{|c|}{ MNC/Culture } & \multicolumn{2}{|c|}{ MNC/Culture } \\
\hline Media & $22 \pm 5$ & $18 \pm 3$ & $6 \pm 1$ & 0 \\
\hline IL-1 & $501 \pm 80^{*}$ & $429 \pm 40^{*}$ & $10 \pm 2$ & 0 \\
\hline
\end{tabular}

Human bone marrow or peripheral blood mononuclear cells were cultured with or without purified IL-1 $(100 \mathrm{U} / \mathrm{ml})$. After 3 wk of culture cells were fixed, stained, and MNCs were scored. The results were expressed as the mean \pm SEM for three or four cultures.

$* P<0.01$ compared to cultures lacking added IL-1. 


\section{Control}

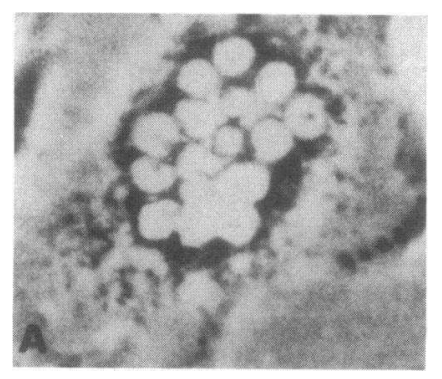

Osteoclasts
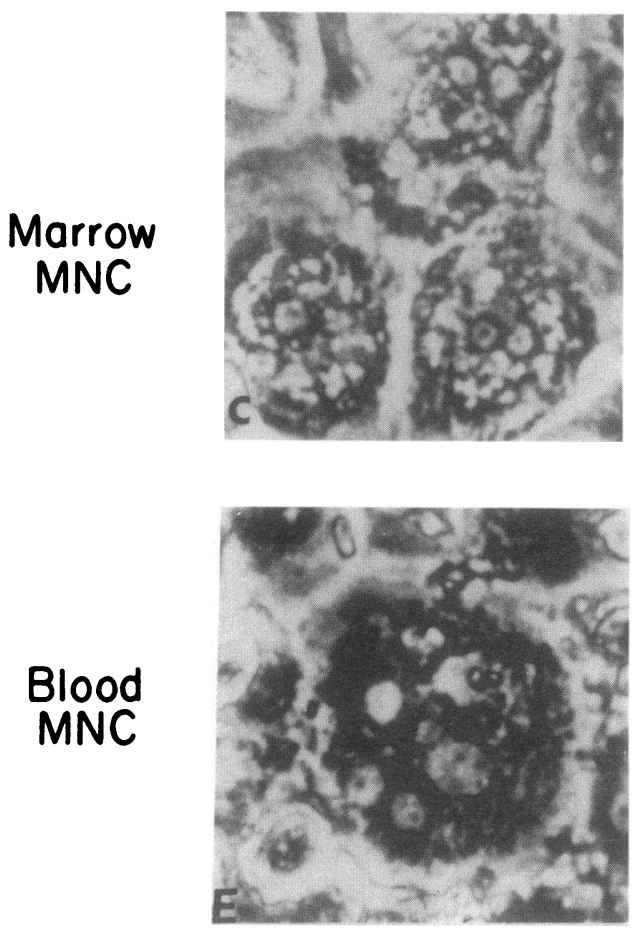

\section{Calcitonin Treated}
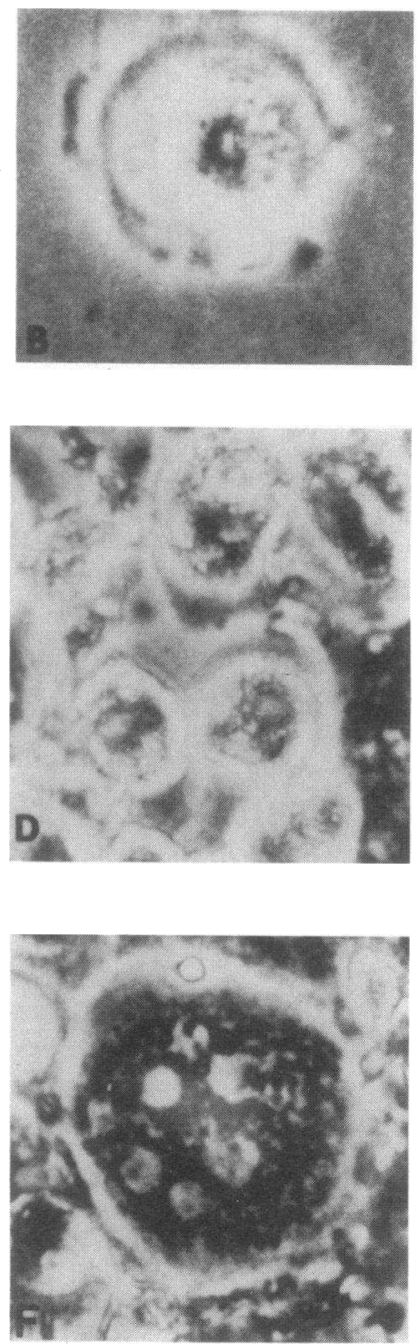

Figure 6. Effects of calcitonin on the morphology of isolated osteoclasts, bone marrow-derived MNCs or peripheral blood-derived MNCs. Baboon osteoclasts ( $A$ and $B)$, bone marrow-derived MNCs ( $C$ and $D$ ) and peripheral blood-derived MNCs $(E$ and $F$ ) were prepared as described in the Methods. The cells were photographed for $16 \mathrm{~h}$ as controls $(A, C$, and $E)$. Calcitonin $(100 \mathrm{ng} / \mathrm{ml})$ was then added to cultures and the cells were photographed for $16 \mathrm{~h}$ after addition of calcitonin $(B, D$, and $F)$. Note the marked cytoplasmic contraction of osteoclasts $(B)$ and bone marrow-derived MNCs $(D)$ in the presence of calcitonin for $2 \mathrm{~h}$.

\section{Discussion}

Formation of multinucleated cells in bone marrow but not peripheral blood cultures is appropriately regulated by osteotropic hormones and factors. PTH, TGF- $\alpha$, EGF, and IL-1, which stimulate osteoclastic bone resorption in vitro, increased the number of multinucleated cells in bone marrow but had no significant effect on peripheral blood cultures. Calcitonin inhibited multinucleated cell formation stimulated by $1,25 \mathrm{D}_{3}$ or PTH in bone marrow $\sim 50 \%$ but did not inhibit multinucleated cell formation in peripheral blood cultures. In addition, calcitonin induced marked morphological changes in bone marrow-derived multinucleated cells and isolated bone-derived osteoclasts but not peripheral blood-derived multinucleated cells. Further, marrow-derived multinucleated cells but not peripheral blood-derived multinucleated cells formed resorption lacunae on sperm whale dentine. Thus, osteoclasts or cells closely related to osteoclasts form in longterm human marrow cultures, although not all the multinucleated cells formed in bone marrow cultures have characteristics of osteoclasts. Only $50 \%$ of multinucleated cells formed in long-term marrow cultures contracted in response to calci- tonin, and calcitonin only inhibited multinucleated cell formation stimulated by $1,25 \mathrm{D}_{3}$ or PTH by $50 \%$. Further, $1-10 \%$ of multinucleated cells formed resorption lacunae on dentine slices. These results suggest that approximately one-half of the multinucleated cells in long-term marrow cultures express osteoclast characteristics, and not all of these cells form resorption lacunae. Dempster and co-workers (28) have recently reported studies using isolated fetal human osteoclasts on bone slices and found that these osteoclasts resorbed 0.02-0.3 lacunae per osteoclast. These data suggest that only a subpopulation of human osteoclasts form resorption lacunae, and is consistent with our results with human marrow derived multinucleated cells. In addition, preliminary studies (29) have shown that 50 to $70 \%$ of multinucleated cells formed in bone marrow cultures stimulated with $1,25 \mathrm{D}_{3}$ cross-react with osteoclast-specific monoclonal antibodies $23 \mathrm{c} 6$ and $13 \mathrm{c} 2$ (30).

Our data also suggest that macrophage polykaryons rather than osteoclast-like cells are formed in peripheral blood cultures because $(a)$ only $1,25 \mathrm{D}_{3}$ among the osteotropic hormones and factors tested stimulated multinucleated cell formation in peripheral blood cultures. This hormone has been shown to promote the maturation of mononuclear phagocytes 

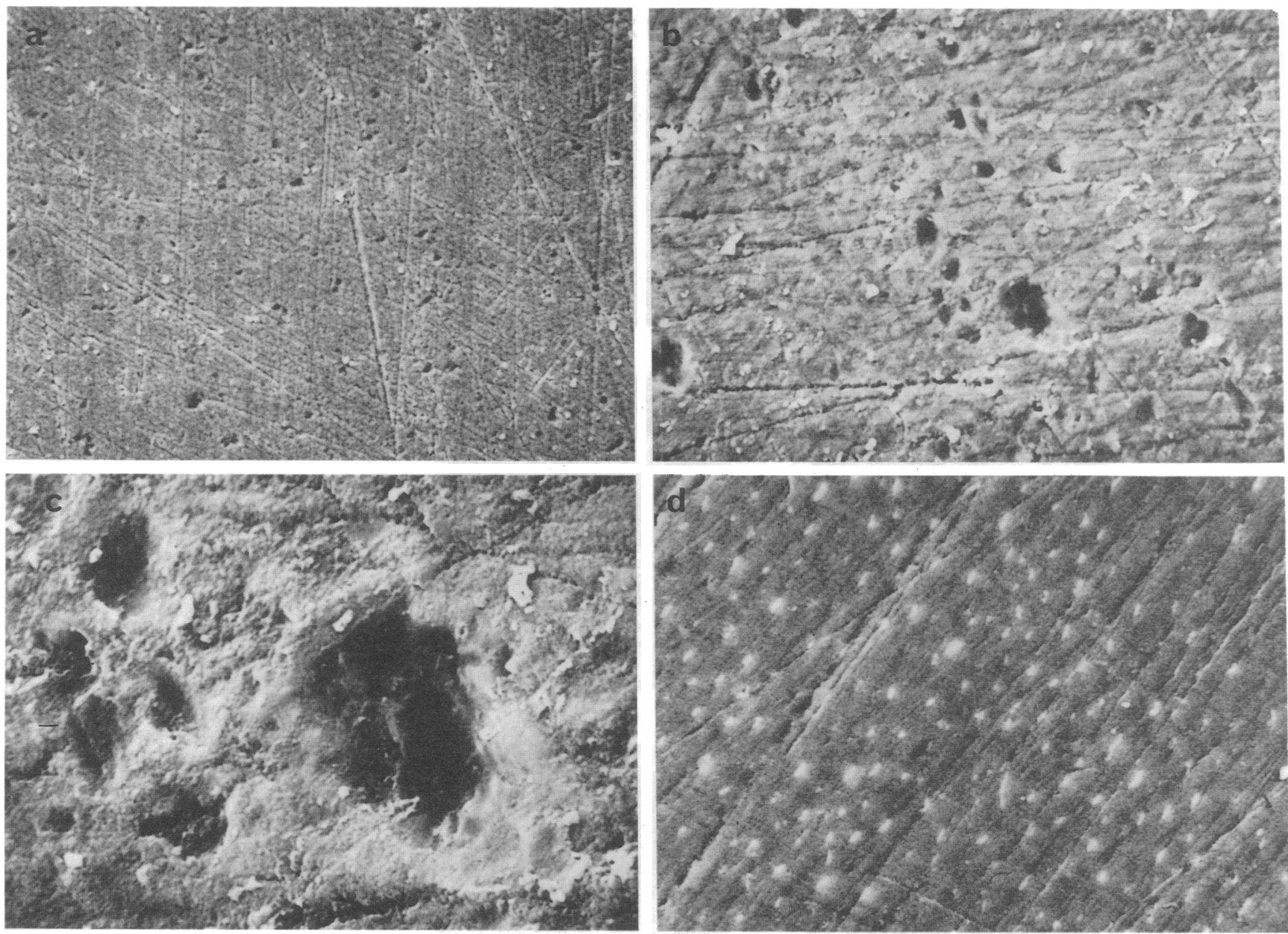

Figure 7. Resorption lacunae formed by marrow-derived multinucleated cells on sperm whale dentine. Bone marrow derived multinucleated cells were cultured with sperm whale dentine in the presence of $1,25 \mathrm{D}_{3}\left(10^{-8} \mathrm{M}\right)$ as described in Methods. The dentine was then fixed and processed for scanning electron microscopy. Control dentine slices were incubated in a similar manner in the absence of cells. (a) Low magnification of dentine slice. Note the many lacunae. $\times 160$. (b) Higher magnification of resorption lacunae. $\times 640$. (c) Details of several resorption lacunae. $\times 2,500$. (d) Control dentine slice. Note the absence of resorption lacunae. $\times 640$.

and to induce the formation of macrophage polykaryons in other culture systems (31-34); (b) calcitonin had no effect on formation or morphology of peripheral blood-derived multinucleated cells. Chambers and Magnus (21) reported that calcitonin only affects osteoclasts and not macrophage polykaryons. Our time-lapse cinemicrography studies showed that peripheral blood-derived multinucleated cells lacked responsiveness to calcitonin; $(c)$ peripheral blood derived multinucleated cells did not form resorption lacunae on dentine. $(d)$ In preliminary studies (29) have recently shown that less than 5\% of multinucleated cells formed in peripheral blood cultures stimulated with $1,25 \mathrm{D}_{3}$ cross-react with osteoclast-specific monoclonal antibodies $23 \mathrm{c} 6$ or $13 \mathrm{c} 2$ (30). It is conceivable that peripheral blood cells may be more mature than marrow cells and have an increased ability to fuse. Osteotropic factors may increase the number of nuclei per multinucleated cell in peripheral blood cultures without increasing the total number of multinucleated cells. However, since these bloodderived multinucleated cells did not express functional characteristics of osteoclasts, this possibility was not assessed. These data suggest that peripheral blood-derived multinu- cleated cells may be macrophage polykaryons whose formation is stimulated by $1,25 \mathrm{D}_{3}$.

Interestingly, the multinucleated cells formed in bone marrow and peripheral blood cultures both contained tartrate-resistant acid phosphatase, a marker enzyme of osteoclasts. Osdoby et al. (35) reported that multinucleated cells formed in monocyte cultures contain tartrate-resistant acid phosphatase. Similarly Snipes et al. (36) showed that monocytes cultured for $3 \mathrm{~d}$ express tartrate-resistant acid phosphatase activity. These data suggest that in cultured cells, tartrateresistant acid phosphatase may not be a specific marker for osteoclast-like cells.

Parabiotic and transplantation studies have suggested that osteoclast precursors are present in peripheral blood. However, unlike bone marrow cultures, the peripheral blood mononuclear cells did not form multinucleated cells with characteristics of osteoclasts in long-term cultures. Burger et al. (37) examined the capacity of various populations of mononuclear phagocytes to form osteoclasts in stripped bone rudiments and reported that bone marrow but not peripheral blood mononuclear cells formed osteoclasts when co-cultured 
with bone rudiments. We have shown that the precursor for osteoclast-like multinucleated cells in bone marrow culture is a nonadherent very immature marrow monocyte (38). In contrast, removal of adherent cells from peripheral blood mononuclear cells markedly decreased the multinucleated cell formation in peripheral blood cultures (data not shown). These results suggest that under the culture conditions used in these experiments, in peripheral blood cultures are not osteoclasts. We cannot exclude that using other culture techniques, osteoclasts may be formed by peripheral blood cells in vitro.

In summary, osteotropic hormones and factors regulated multinucleated cell formation in bone marrow cultures. Calcitonin induced cytoplasmic contraction and decreased motility in multinucleated cells formed in bone marrow cultures, and marrow-derived multinucleated cells formed resorption lacunae on dentine. In contrast PTH, calcitonin, IL-1, TGF- $\alpha$, and EGF had no effect on multinucleated cell formation in peripheral blood cultures, and the multinucleated cells formed in these cultures failed to resorb dentine. These data suggest that long-term human bone marrow culture systems should be useful for evaluating the cell biology of human osteoclasts.

\section{Acknowledgments}

We thank Mrs. Joye Laderer for typing the manuscript.

This work was supported by Research Funds from the Veterans Administration and grants AM-35188 from the National Institutes of Arthritis, Diabetes, Digestive and Kidney Diseases, HL-31264 from the Heart, Lung and Blood Institute, and CA-40035 from the National Cancer Institute.

\section{References}

1. Mundy, G. R., and G. D. Roodman. 1987. Ontogeny and function of the osteoclast. Bone Miner. Res. 5:209-281.

2. Marks, S. C., Jr. 1983. The origin of the osteoclast. J. Oral Pathol. 12:226-256.

3. MacDonald, B. R., N. Takahashi, L. M. McManus, J. Holahan, G. R. Mundy, and G. D. Roodman. 1987. Formation of multinucleated cells which respond to osteotropic hormones in long-term human bone marrow cultures. Endocrinology. 120:2326-2333.

4. Takahashi, N., B. R. MacDonald, J. Hon, M. E. Winkler, R. Derynck, G. R. Mundy, and G. D. Roodman. 1986. Recombinant human transforming growth factor alpha stimulates the formation of osteoclast-like cells in long term human marrow cultures. J. Clin. Invest. 78:894-898.

5. Takahashi, N., G. R. Mundy, and G. D. Roodman. 1986. Recombinant human gamma-interferon inhibits formation of human osteoclast-like cells by inhibiting the fusion of their precursors. $\mathrm{J}$. Immunol. 137:3544-3549.

6. Walker, D. G. 1973. Osteopetrosis cured by temporary parabiosis. Science (Wash. DC). 180:875.

7. Gothlin, G., and J. L. E. Ericsson. 1973. On the histogenesis of cells in fracture callus. Electron microscopic autoradiographic observations in parabiotic rats and studies on labelled monocytes. Virchows Arch. Cell Pathol. 12:318-329.

8. Walker, D. G. 1972. Congenital osteopetrosis in mice cured by parabiotic union with normal siblings. Endocrinology. 91:916-920.

9. Zambonin Zallone, A., A. Teti, and M. V. Primavera. 1984. Monocytes from circulating blood fuse in vitro with purified osteoclasts in primary culture. J. Cell. Sci. 66:335-342.

10. Ibbotson, K. J., J. Harrod, M. Gowen, S. D’Souza, D. D. Smith, M. E. Winkler, R. Derynck, and G. R. Mundy. 1986. Human recombinant transforming growth factor-alpha stimulates bone resorption and inhibits formation in vitro. Proc. Natl. Acad. Sci. USA. 83:2228-2232.
11. Ibbotson, K. J., S. M. D'Souza, K. W. Ng, C. K. Osborne, M. Niall, T. J. Martin, and G. R. Mundy. 1983. Tumor-derived growth factor increases bone resorption in a tumor associated with humoral hypercalcemia of malignancy. Science (Wash. DC). 221:1292-1294.

12. Ibbotson, K. J., D. R. Twardzik, S. M. D'Souza, W. R. Hargreaves, G. J. Todaro, and G. R. Mundy. 1985. Stimulation of bone resorption in vitro by synthetic transforming growth factor-alpha. Science (Wash. DC). 228:1007-1009.

13. Tashjian, A. H., E. F. Voelkel, M. Lazzaro, F. R. Singer, A. B. Roberts, R. Derynck, M. E. Winkler, and L. Levine. 1985. $\alpha$ and $\beta$ human transforming growth factors stimulate prostaglandin production and bone resorption in cultured mouse calvaria. Proc. Natl. Acad. Sci. USA. 82:4535-4538.

14. Stern, P. H., N. S. Krieger, R. A. Nissenson, R. D. Williams, M. F. Winkler, R. Derynck, and G. J. Strewler. 1985. Human transforming growth factor-alpha stimulates bone resorption in vitro. $J$. Clin. Invest. 76:2016-2019.

15. Tashjian, A. H., and L. Levine. 1978. Epidermal growth factor stimulates prostaglandin production and bone resorption in cultured mouse calvaria. Biochem. Biophys. Res. Commun. 85:966-975.

16. Raisz, L. G., H. A. Simmons, A. L. Sandberg, and E. Canalis. 1980. Direct stimulation of bone resorption by epidermal growth factor. Endocrinology. 107:270-273.

17. Gowen, M., D. D. Wood, E. J. Ihrie, M. K. B. McGuire, and R. G. G. Russell. 1983. An interleukin 1 like factor stimulates bone resorption in vitro. Nature (Lond.). 306:378-380.

18. Health, J. K., J. Saklatvala, M. C. Meikle, S. J. Atkinson, and J. J. Reynolds. 1985. Pig interleukin 1 (catabolin) is a potent stimulator of bone resorption in vitro. Calcif. Tissue Int. 37:95-97.

19. Dewhirst, F. E., P. P. Stashenko, J. E. Mole, and T. Tsurumachi. 1985. Purification and partial sequence of human osteoclast-activating factor: identity with interleukin $1 \beta$. J. Immunol. 135:25622568.

20. Gowen, M., and G. R. Mundy. 1986. Actions of recombinant interleukin 1, interleukin 2 and interferon- $\gamma$ on bone resorption in vitro. J. Immunol. 136:2478-2482.

21. Chambers, T. J., and C. J. Magnus. 1982. Calcitonin alters behavior of isolated osteoclasts. J. Pathol. 136:27-39.

22. Jones, S. J., A. Boyde, N. N. Ali, and E. Maconnachie. 1986. Variation in the sizes of resorption lacunae made in vitro. Scanning Electron Microsc. 4:1571-1580.

23. Boyde, A., N. N. Ali, and S. J. Jones. 1985. Optical and scanning electron microscopy in the single osteoclast resorption assay. Scanning Electron Microsc. 3:1259-1271.

24. Chambers, T. J., P. M. J. McSheehy, B. M. Thomson, and K. Fuller. 1985. The effect of calcium-regulating hormones and prostaglandins on bone resorption by osteoclasts disaggregated from neonatal rabbit bones. Endocrinology. 116:234-239.

25. Chambers, T. J., P. A. Revell, K. Fuller, and N. A. Athanasou. 1984. Resorption of bone by isolated rabbit osteoclasts. J. Cell Sci. 66:383-399.

26. Ali, N. N., S. J. Jones, and A. Boyde. 1984. Monocyte-enriched cells on calcified tissue. Anat. Embryol. 170:169-175.

27. Chambers, T. J., and M. A. Horton. 1984. Failure of cells of the mononuclear phagocyte to series to resorb bone. Calcif. Tissue Int. 35:556-558.

28. Murrills, R. J., E. Shane, R. Linsday, and D. W. Dempster. 1988. Bone resorption by isolated human osteoclasts. Calcif. Tissue Int. 42(Suppl.):A23.

29. Kukita, T., C. Civin, L. M. McManus, and G. D. Roodman. 1988. Surface phenotype analysis of osteoclast-like cells formed in long term human marrow cultures. J. Bone Miner. Res. 3(Suppl.):S101.

30. Horton, M. A., D. Lewis, K. McNulty, J. A. S. Pringle, and T. J. Chambers. 1985. Monoclonal antibodies to osteoclastomas (giant cell bone tumors). Definition of osteoclast-specific cellular antigens. Cancer Res. 45:5663-5669.

31. Tanaka, H., E. Abe, C. Miyaura, Y. Shiina, and T. Suda. 1983. 
$1 \alpha, 25$-Dihydroxyvitamin $\mathrm{D}_{3}$ induces differentiation of human promyelocytic leukemia cells (HL-60) into monocyte-macrophages, but not into granulocytes. Biochem. Biophys. Res. Commun. 117:86-92.

32. McCarthy, D. M., J. F. San Miguel, H. C. Freake, P. M. Green, H. Zola, D. Catovsky, and J. M. Goldman. 1983. 1,25-Dihydroxyvitamin $D_{3}$ inhibits proliferation of human promyelocytic leukemia (HL60) cells and induces monocyte-macrophage differentiation on HL60 and normal human bone marrow cells. Leukemia Res. 7:51-58.

33. Bar-Shavit, Z., S. L. Teitelbaum, P. Reitsma, A. Hall, L. E. Pegg, J. Trial, and A. J. Kahn. 1983. Induction of monocytic differentiation and bone resorption by 1,25-dihydroxyvitamin $\mathrm{D}_{3}$. Proc. Natl. Acad. Sci. USA. 80:5907-5911.

34. Abe, E., Y. Shiina, C. Miyaura, H. Tanaka, T. Hayashi, S. Kanegasaki, M. Saito, Y. Nishii, H. F. DeLuca, and T. Suda. 1986. Activation and fusion induced by 1,25-dihydroxyvitamin $\mathrm{D}_{3}$ and their relation in alveolar macrophages. Proc. Natl. Acad. Sci. USA. 81:7112-7116.
35. Osdoby, P., M. C. Martini, and A. I. Caplan. 1982. Isolated osteoclasts and their presumed progenitor cells, the monocyte, in culture. J. Exp. Zool. 224:331-344.

36. Snipes, R. G., K. W. Lam, R. C. Dodd, T. K. Gray, and M. S. Cohen. 1986. Acid phosphatase activity in mononuclear phagocytes and the U937 cell lines. Monocyte-derived macrophages express tartrate-resistant acid phosphatase. Blood. 67:729-734.

37. Burger, E. H., J. W. M. Van der Meer, J. S. Van De Gevel, J. C. Gribnau, C. W. Thesingh, and R. Van Furth. 1982. In vitro formation of osteoclasts from long term cultures of bone marrow mononuclear phagocytes. J. Exp. Med. 156:1604-1616.

38. Roodman, G. D., K. J. Ibbotson, B. R. MacDonald, T. J. Kuehl, and G. R. Mundy. 1985. 1,25-Dihydroxyvitamin $D_{3}$ causes formation of multinucleated cells with several osteoclast characteristics in cultures of primate marrow. Proc. Natl. Acad. Sci. USA. 82:82138217. 